\title{
PSMB8 wt Allele
}

National Cancer Institute

\section{Source}

National Cancer Institute. PSMB8 wt Allele. NCI Thesaurus. Code C112076.

Human PSMB8 wild-type allele is located in the vicinity of $6 \mathrm{p} 21.3$ and is approximately 4 $\mathrm{kb}$ in length. This allele, which encodes proteasome subunit beta type- 8 protein, is involved in both antigen processing and protein catabolism. Mutation of the gene is associated with Nakajo syndrome and chronic atypical neutrophilic dermatosis with lipodystrophy and elevated temperature syndrome (CANDLE syndrome). 